\title{
EkoMiasto\#Gospodarka
}

Zrównoważony, inteligentny i partycypacyjny rozwój miasta

pod redakcją

Aleksandry Nowakowskiej

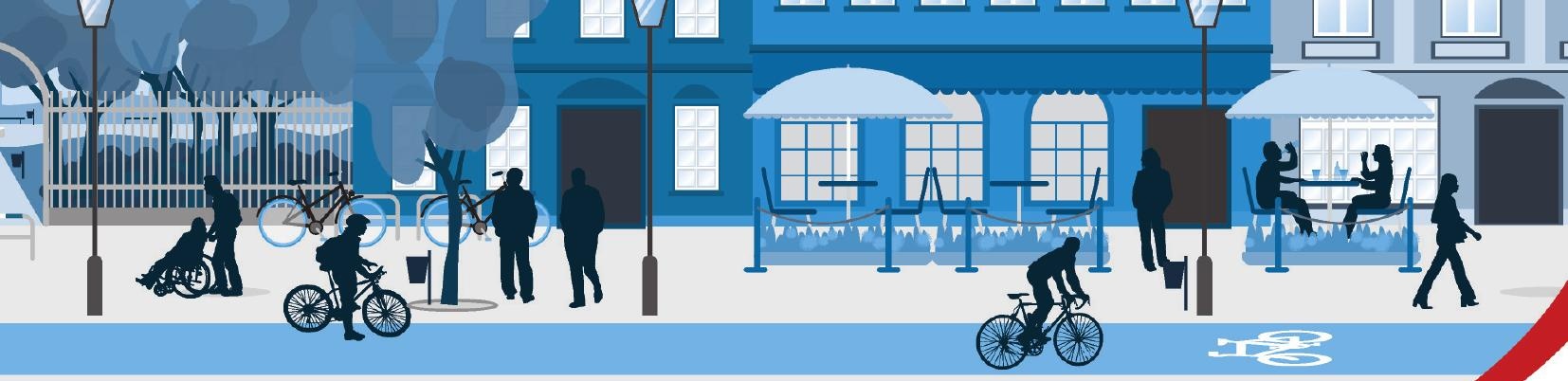


http://dx.doi.org/10.18778/7969-968-1.02

Aleksandra Jewtuchowicz*

Mariusz E. Sokołowicz **

Jakub Zasina***

\section{ZROZUMIEĆ FENOMEN MIASTA}

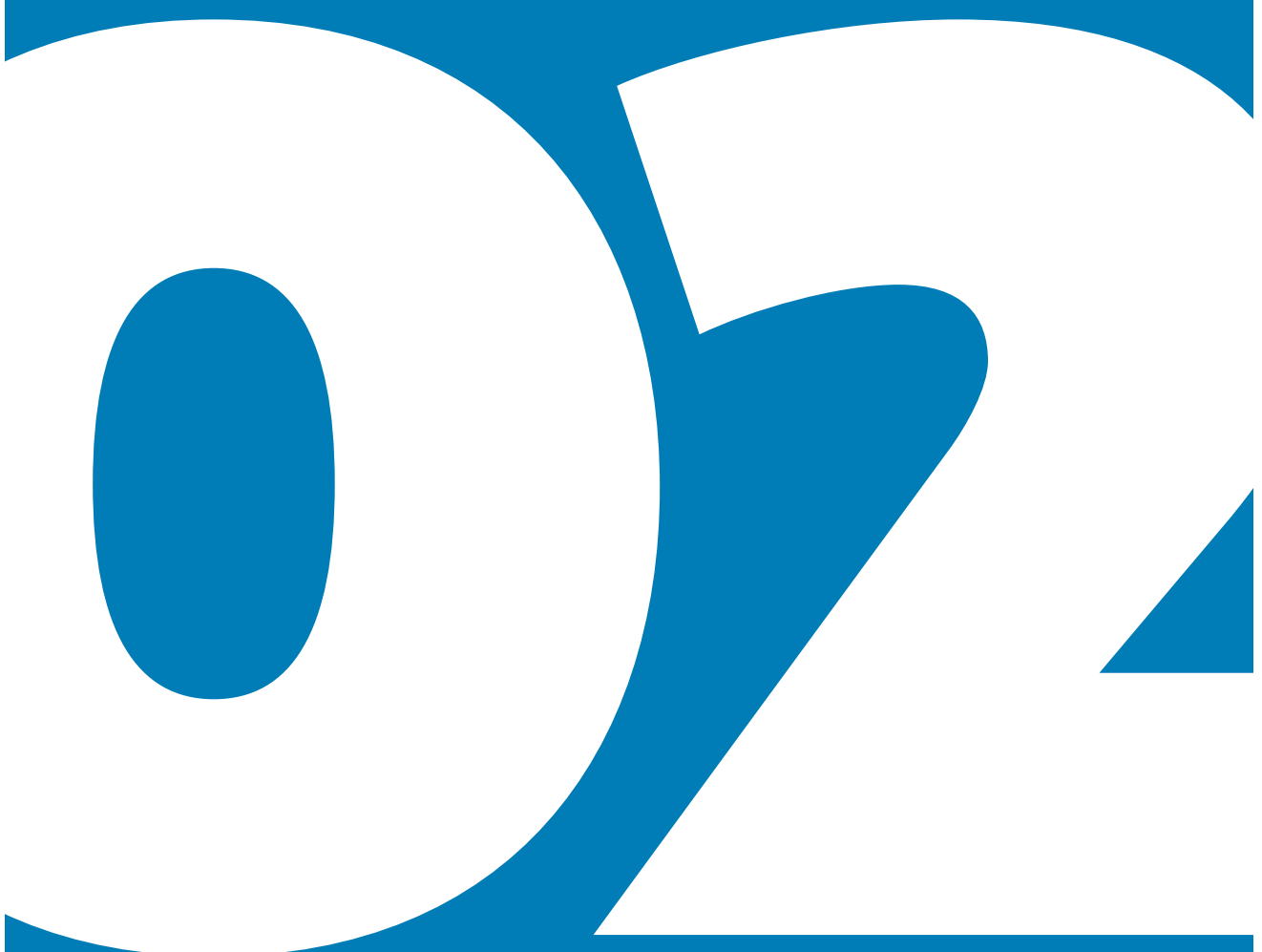

*Prof. dr hab, Uniwersytet Łódzki, Wydział Ekonomiczno-Socjologiczny, Katedra Gospodarki Regionalnej i Środowiska, e-mail: jewtuch@uni.lodz.pl

${ }^{* *}$ Dr, Uniwersytet Łódzki, Wydział Ekonomiczno-Socjologiczny, Katedra Gospodarki Regionalnej i Środowiska, e-mail: mariusz.sokolowicz@uni.lodz.pl

${ }^{* * *}$ Mgr, Uniwersytet Łódzki, Wydział Ekonomiczno-Socjologiczny, Katedra Gospodarki Regionalnej i Środowiska, e-mail: jakub.zasina@uni.lodz.pl 


\subsection{Od miasta do metropolii. Rys historyczny powstawania i ewolucji miast}

Mimo rozległości przestrzeni, jaką oferuje Ziemia, coraz większych możliwości telekomunikacji na duże odległości oraz mimo coraz niższych kosztów transportu ludzie wciąż zamieszkują i pracują obok siebie - właśnie w miastach [Glaeser, 2012, s. 1]. Miasta zawsze były (i nadal są) kolebką cywilizacji, źródłem innowacyjności i kreatywności zapewniającym rozwój nauki i idei. Miasta istnieją od zarania dziejów i mają wielowiekową tradycję. Historia powstawania i rozwoju miast jest długa, a osadnictwo to bardzo stara forma organizacji społeczeństw. Kiedy przyglądamy się historii kilku ostatnich tysiącleci, widzimy, jak kształtowały się zręby cywilizacji. Organizm społeczny stawał się coraz bardziej złożony. Najpierw były wsie, utorowały one drogę grodom, grody miastom-państwom, miasta-państwa państwom [Claval, 1981, s. 15-27]. Kształtowanie się coraz bardziej skomplikowanych układów było skutkiem ewolucji kulturowej. Samo zgrupowanie ludzi na określonej przestrzeni nie staje się bowiem automatycznie miastem. Tym, co daje im takie miano, jest ich organizacja społeczna, a przede wszystkim zróżnicowanie wewnętrzne i podział zadań między poszczególne grupy w danej zbiorowości.

Pierwsze miasta pojawiły się w epoce neolitycznej, około 10 tysięcy lat przed naszą erą, w ramach kilku ośrodków cywilizacji: Mezopotamii, Egiptu, północnych Indii, Chin. P. Claval twierdził, że historycznie pierwszą przyczyną pochodzenia „siedlisk ludzkich" były szczególnie dobre warunki do polowania w określonym miejscu [Claval, 1981, s. 27]. W miarę upływu czasu i opanowania bardziej złożonych technik zdobywania pożywienia, przede wszystkim hodowli i upraw, zamieszkiwanie ludzi w jednym miejscu stało się zjawiskiem stałym i normalnym. Miejsca te rozlokowane były na przestronnych równinach dobrze zaopatrzonych w wodę, gdzie postęp w rolnictwie pozwalał na zwiększenie produkcji żywności i uwolnienie części społeczeństwa od pracy na ziemi. Początkowo proces urbanizacji przebiegał bardzo wolno. Jeszcze do końca XIX wieku ludność naszej planety zajmowała się głównie rolnictwem i zamieszkiwała na wsi i w małych miastach, które pełniły funkcje rynków wymiany nadwyżek produkcyjnych lub etapów w podróży, gdzie zatrzymywali się wędrowcy. Tylko niektóre z nich zaczęły z czasem sprawować kontrolę nad większymi przestrzeniami, jak np. starożytny Rzym, który w okresie swego największego rozkwitu przekroczył milion mieszkańców, lub Edo (dawne Tokio), które liczbę miliona osób osiągnęło w XVIII wieku. W 1800 roku tylko 8\% mieszkańców świata żyło w miastach, a największe z nich znajdowały się w Chinach i w Europie [Bloc-Duraffour, 1998, s. 6].

W sto lat później, w 1900 roku, stopa urbanizacji wrosła do 10\%. Na początku XX wieku jeszcze ponad 60\% ludności Francji mieszkało na wsi, a głównym ich zajęciem było rolnictwo. W Szwajcarii wskaźnik ten wyniósł w tym okresie ponad 75\%, w Kanadzie około 63\%, a w Japonii więcej niż 80\%. Jedynie Wielka Brytania i kraje północnej Europy były bardziej zurbanizowane [Polèse, 1994, s. 13]. Rosnąca liczba ludności i zmiany gospodarcze spowodowały stały wzrost znaczenia miast. Wynikało to m.in. z tego, że ceny produktów będących efektem działalności przemysłowej rosły, podczas gdy ceny produktów rolnych malały. W konsekwencji ośrodki miejskie rozwijały się szybciej niż wieś i już od XV wieku zaobserwowano uzależnianie się gospodarek poszczególnych państw od ekonomicznej siły ich miast.

Kumulujący się efekt wzrostu liczby ludności i stopy urbanizacji dał niespotykany do tej pory wzrost miast. Między rokiem 1500 a 1700 ludność miast europejskich nie wzrastała więcej niż 0,2\% w ciągu roku. Jednak już w latach 1750-1910 wzrost ten osiągnął rocznie 1,4\%, a w kolejnym okresie (1850-1910) przyspieszył do $2,0 \%$ rocznie. Tym samym w latach $1900-1990$ liczba ludności ${ }^{1}$ na świecie wzrosła 
o $330 \%$, a poziom urbanizacji o $450 \%$. Przekładało się to nie tylko na powstawanie nowych miast, ale w znacznej mierze na powiększania się już istniejących. Przykładowo w latach 1890-1990 populacja Tokio powiększyła się 23-krotnie [Polèse, 1994, s. 14]. Wzrost odnotowywały także miasta Europy Zachodniej, gdzie liczba miast o populacji większej niż 100000 wzrosła w okresie 1800-1870 z 16 do 63 [Bairoch, 1977, s. 18].

Tabela 2.1. Wzrost liczby ludności największych miast świata w latach 1800-1941

\begin{tabular}{|c|r|r|r|r|r|}
\hline \multicolumn{1}{|c|}{ Lata } & \multicolumn{1}{l|}{ Londyn } & \multicolumn{1}{c|}{ Paryż } & \multicolumn{1}{c|}{ Berlin } & Nowy Jork & Chicago \\
\hline $1800-1801$ & 1117000 & 547000 & 172000 & 60000 & - \\
\hline $1850-1851$ & 2685000 & 1053000 & 419000 & 316000 & 30000 \\
\hline $1880-1881$ & 4770000 & 1269000 & 1212000 & 1165000 & 503000 \\
\hline $1910-1911$ & 7256000 & 2888000 & 2071000 & 4767000 & 2285000 \\
\hline $1940-1941$ & 8700000 & 2830000 & 4332000 & 7455000 & 3397000 \\
\hline
\end{tabular}

Źródło: Weber, 1899; Flanagan, 1990, cyt. [za:] Majer, 2010, s. 165.

W XV wieku swoje prawa zaczęły ustanawiać rynki miejskie. W wieku XVI pojawiły się międzynarodowe targi, które dały siłę i bogactwo takim ośrodkom, jak Frankfurt, Lyon czy Genua. Rozwój wymiany handlowej związany był z pojawieniem się metali szlachetnych pochodzących z Ameryki Łacińskiej, stanowił zatem pewną formę ówczesnej globalizacji, będącej efektem procesu kolonizacji. WXVII wieku kapitał zaczynał przemieszczać się na północ, co zaowocowało silnym wzrostem roli Amsterdamu. Dotychczasowe rynki jako miejsca bezpośrednich spotkań ustąpiły pola giełdom. Genewa i Genua wyspecjalizowały się w pożyczkach międzynarodowych. Powstawały kolejne centra tworzące i ożywiające różnego rodzaju ośrodki gospodarcze. Do około 1750 roku dominującymi były nadal miasta lub państwa-miasta. Od połowy XVIII wieku rozpoczęła się nowa era. Londyn nie był już miastem-państwem, lecz stolicą kraju, który tworzył krajowy rynek zbytu dla ekspansji kapitalizmu przemysłowego w XIX i XX wieku [zob. Duché, 2010, s. 7-13].

Historyczna analiza rozwoju miast pozwala wyróżnić dwie fazy przyśpieszonej urbanizacji. Pierwsza przypada na lata 1830/1840-1900, czyli na okres pierwszej rewolucji przemysłowej. Stanowiła ona skutek dynamicznego rozwoju biegunów wzrostu oraz korzyści skali. Szybki rozwój środków transportu wyzwolił miasto z ograniczeń przestrzennych. Industrializacja umożliwiła powstawanie nowych ośrodków i rozwój niektórych miast. Działalność gospodarcza koncentrowała się

\footnotetext{
${ }^{1}$ Od starożytności do początku XVII wieku stopa wzrostu liczby mieszkańców Ziemi była na tyle niska, że podawano w wątpliwość, czy kiedykolwiek przekroczy pół miliarda. Następnie liczba ludności zaczyna wzrastać bardzo szybko, szczególnie po 1900 roku. W roku 1900 liczba ludności świata przekracza 1,6 mld, w końcu XX wieku liczy już ponad 6 mld, a w 2015 osiąga ponad 7,3 miliarda ludzi.
} 
wokół miejsc wydobycia surowców naturalnych, rynków handlowych, jak też przy szlakach komunikacyjnych dających dostęp do zasobów i rynków zbytu. W tym czasie w Europie (bez Rosji) przyrost ludności miejskiej kształtował się powyżej 1,9\% w skali rocznej, a stopa urbanizacji wzrastała o 1,2\% rocznie [Bairoch, 1977, s. 18-19].

Druga faza obejmuje lata po roku 1945. W roku 1950 liczba mieszkańców miast wynosiła ponad 735 milionów w stosunku do 2,5 miliarda ludności ogółem, a 85 aglomeracji przekroczyło milion mieszkańców. W 1995 roku ludność miejska liczyła już 2,6 miliarda przy 5,7 miliarda ludności ogółem, stopa urbanizacji zaś osiągnęła poziom 46\% [Bloc-Duraffour, 1998, s. 6]. Z kolei w 2000 roku liczba ludności świata przekroczyła 6 miliardów przy stopie urbanizacji większej niż 47\%, i coraz silniej skupiona jest $w$ wielomilionowych miastach i otaczających je zespołach miejskich. Możemy więc stwierdzić za Clavalem, że w XX wieku „świat, w którym żyjemy, stał się światem miast" [Claval, 1981, s. 2].

Stwierdzenie to szczególnie dotyczy Europy, której cywilizacja dużo zawdzięcza roli, jaką odegrały w historii takie miasta, jak Rzym, Wenecja, Paryż, Amsterdam, Wiedeń lub Londyn. Jak pisał Benevolo: „Miasta europejskie rodziły się wraz z Europą i w pewnym sensie sprzyjały również jej narodzinom" [Benevolo, 1995, s. 9]. Są one uosobieniem i przedłużeniem trwałych, liczących całe stulecia procesów, leżących u podstaw europejskiej historii. Europa od 2000 lat jest kontynentem miast, które zawsze były podstawowym czynnikiem ekspansji ekonomicznej i ośrodkami wpływów kulturowych.

\section{Poziom urbanizacji na świecie}

Podstawową statystyką wykorzystywaną do opisu współczesnych gospodarek i społeczeństw jest wskaźnik urbanizacji, który określa procentowy udział ludności miejskiej w ogólnej liczbie ludności (np. kraju). Ostatnie półwiecze charakteryzowało się gwałtownym tempem przyrostu ludności miejskiej w skali świata. Jeszcze na początku lat 60. XX wieku miasta zamieszkiwało tylko nieco ponad 30\% mieszkańców Ziemi. Z kolei już w roku 2009 - po raz pierwszy w dziejach świata - więcej ludzi (51\%) było mieszkańcami miast niż wsi. Udział mieszkańców miast w skali świata konsekwentnie rośnie, co w ostatnich dekadach jest w znacznej mierze wynikiem urbanizacji krajów azjatyckich, południowoamerykańskich i afrykańskich. Współcześni badacze miast są również zdania, że trend ten utrzyma się w kolejnych dekadach.

Nieco inaczej prezentuje się sytuacja Polski, która relatywnie szybko osiągnęła poziom urbanizacji na poziomie $50 \%$ (nastąpiło to w roku 1964). Do intensyfikacji procesów urbanizacji doszło w Polsce w okresie powojennym, co wiązało się z prowadzoną wówczas industrializacją kraju. Wskaźnik urbanizacji dla Polski osiągnął swój szczyt w latach 1996-2004, kiedy to wynosił 62\%. Od tamtej pory obserwuje się tendencję polegającą na zmniejszaniu udziału ludności miejskiej w społeczeństwie polskim. Źródłami tego zjawiska są m.in. depopulacja wybranych miast, a także procesy suburbanizacji, czyli przenoszenia się ludności miejskiej do stref podmiejskich (często pozostających terenami wiejskimi pod względem administracyjnym).

Czynnikiem, który zdynamizował procesy urbanizacji, było uprzemysłowienie. Przemysł rozwijał się i rozprzestrzeniał w następujących po sobie fazach, które w sposób decydujący wpływały na organizację systemu osadniczego i pozycję poszczególnych miast. Bloc-Duraffour wyróżnia kilka „generacji” przemysłowych według dominujących źródeł energii, rodzaju motorycznych gałęzi i ich wpływu na rozwój 
i urbanistykę miast [Bloc-Duraffour, 1998, s. 40]. Według tego autora pierwsza rewolucja przemysłowa XIX wieku była oparta na węglu kamiennym, maszynie parowej i włókiennictwie, a następnie na kolei żelaznej i metalurgii. Daje ona początek miastom położonym w regionach wydobywczych i na skrzyżowaniu dróg kolejowych i portów.

Rysunek 2.1. Udział ludności miejskiej na świecie w latach 1950-2015 wraz z prognozą do roku 2045

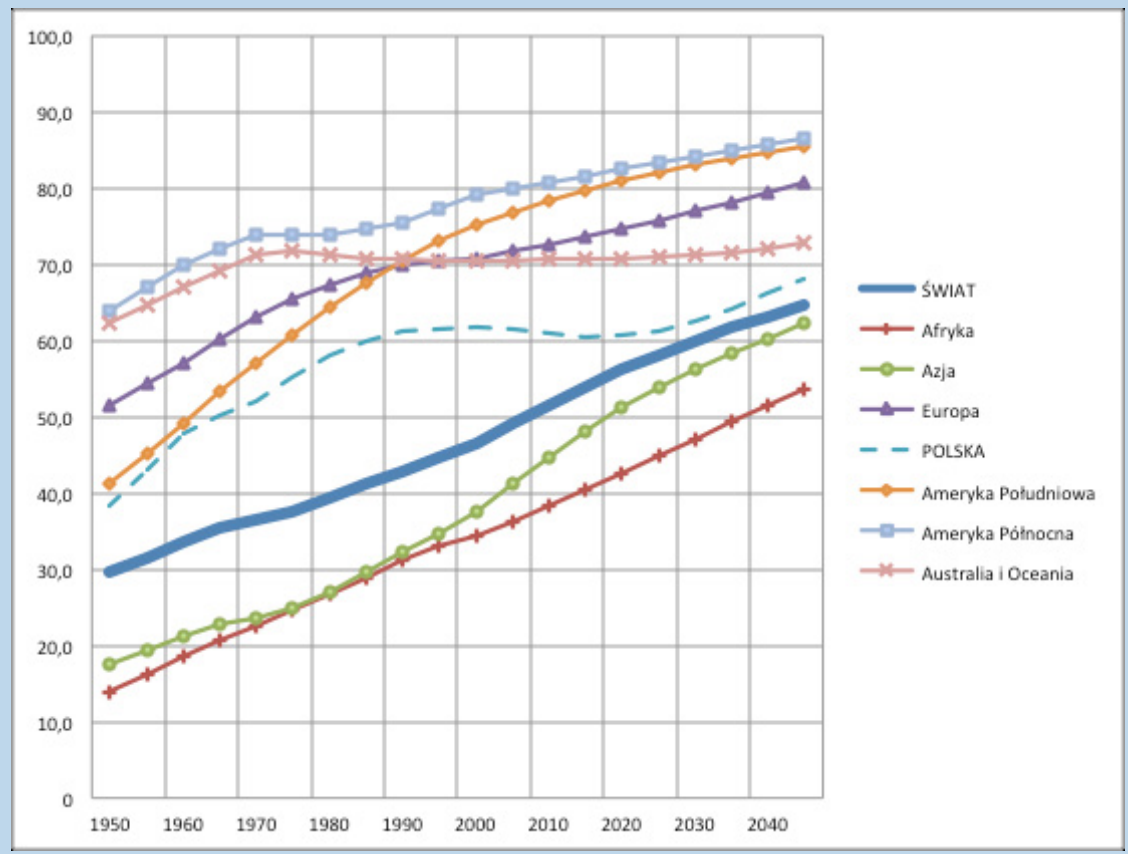

Źródto: opracowanie wlasne na podstawie danych ONZ: Population Division of the Department of Economic and Social Affairs of the United Nations Secretariat (2014), World Population Prospects: The 2014 Revision, http:/ / esa. un.org/unpd/wup/CD-ROM/WUP2014_XLS_CD_FILES/WUP2014-F02-Proportion_Urban.xls. [dostepp 12.10.2015]

Druga rewolucja to przełom XIX i XX wieku. Wydobycie węgla kamiennego zajmuje jeszcze naczelną pozycję, ale stopniowo zaczyna wzrastać rola innych źródeł energii, np. ropy naftowej. Mechanika, chemia i przemysły elektryczne zastępują przemysły wydobywcze, rozwój przemysłu samochodowego prowadzi do rozbudowy i wzrostu znaczenia sieci drogowej. Wielkie kompleksy przemysłowe, przyczyniając się do powstawania dużych aglomeracji, powodują szybki wzrost znaczenia ustug.

Współczesna, trzecia rewolucja przemysłowa dotyczy szybkiego transportu, rozkwitu wysokich technologii, dyfuzji informacji. Kładzie nacisk na badania i rozwój w takich dziedzinach, jak: areonautyka, badania kosmosu, wykorzystanie energii jądrowej, elektronika, informatyka i telekomunikacja, biotechnologie i nowe materiały. Rewolucja ta modyfikuje warunki na korzyść miast zdolnych zmobilizować kapitały, przyciągnąć strategiczne zasoby ludzkie, rozwijać synergię między przemysłami. Daje początek jakościowo nowej fazie globalizacji, której konsekwencją jest proces metropolizacji i pojawienie się wielkich metropolii. 


\subsection{Czynniki powstawania i rozwoju miast}

Punktem wyjścia w poszukiwaniu przyczyn, dla których miasta stają się przedmiotem zainteresowań ze strony przedstawicieli nauk ekonomicznych, powinna być odpowiedź na pytanie o podstawowe siły sprawcze powstawania i rozwoju miast. Przyglądając się temu zjawisku w ujęciu historycznym, łatwo dojść do wniosku, że kluczowym generatorem urbanizacji jest czynnik o charakterze społeczno-ekonomicznym, a mianowicie postępujący podział pracy (wynikający ze specjalizacji ludzi w różnych typach zawodów) i zwiększająca się w ślad za tym konieczność wymiany dóbr i usług, będących efektem ludzkiej pracy. Innymi słowy, ludzkość stosunkowo szybko uświadomiła sobie, że poszczególne jednostki, aby efektywniej wykonywać swą pracę, powinny specjalizować się w określonych rodzajach aktywności. Tym samym zaczęły pojawiać się pierwsze zawody (myśliwy, rybak, rolnik, żołnierz, kowal, szewc, kołodziej itp.). Postępująca specjalizacja i podział pracy wymusiły również rozwój zawodu kupca (handlarza), ale, co istotne, kazały poszukiwać warunków do wymiany handlowej. W konsekwencji do głównych czynników powstawania miast zaliczono wyłanianie się działalności pozarolniczych (głównie rzemiosł) i wydzielanie się w ten sposób osad ludzkich z otoczenia rolniczego [Jewtuchowicz, 1987, s. 94-95].

Wraz z rozwojem cywilizacji ludzkiej kolejnym czynnikiem rozwoju miast stały się względy polityczne. Za sprawą wzrostu liczby ludności i jej koncentracji w miastach to właśnie miasta stawały się siedzibami władz, ułatwiając w ten sposób procesy zarządzania większymi terytoriami i dając gwarancję utrzymania panujących stosunków społecznych. Jednakże, historia upadku Aten czy Rzymu pokazuje, że trwale rozwijały się jedynie miasta zbudowane na dobrowolnym handlu. Tymczasem miasta, których egzystencja oparta była jedynie na czynniku politycznym czy militarnym (a zatem - w pewnym sensie - na eksploatacji innych obszarów), wcześniej czy później upadały [O'Sullivan, 2007, s. 21].

W czasach nowożytnych (początkowo już w średniowieczu, a na znacznie większą skalę od czasów rewolucji przemysłowej) kluczowym czynnikiem urbanizacji stała się industrializacja. Także i w tym przypadku siłą sprawczą rozwoju miast okazały się czynniki o charakterze ekonomicznym. O koncentracji działalności przemysłowej w miastach decydowały bowiem mechanizm osiągania korzyści skali w produkcji, możliwość dotarcia do dużej liczby poddostawców i kooperantów w jednym miejscu oraz dostępność siły roboczej wynikająca z koncentracji ludności (por. rys. 2.2). Miasta traktowane były jako miejsca, w których bliskość fizyczna pozwalała ograniczyć koszty zapewniania sobie takiego dostępu.

Zatem większość miast to układy przestrzenne, które wykształciły się historycznie na skutek postępującego podziału pracy. Z czasem zmieniały się jednak uwarunkowania gospodarcze i miasta musiały się do nich przystosowywać. Bez względu na rodzaj czynników miastotwórczych najważniejszą rolę w rozwoju miast odgrywała bliskość (sprzedających, kupujących, instytucji politycznych i gospodarczych, zasobów naturalnych czy zasobów pracy). Z tego powodu ośrodki miejskie powstawały w miejscach pozwalających na pokonywanie oporu przestrzeni, względnie w miejscach zapewniających bezpieczeństwo. Stąd ważnymi czynnikami lokalizacji miast były warunki zapewniające dostęp do surowców, rzek i mórz, stanowiących skrzyżowanie naturalnych dróg bądź gwarantujących obronność. Miasta powstawały też na granicach krain przyrodniczych i geograficznych. Wszystko to pozwalało na ograniczenie kosztów transportu, będących kolejnym ważnym czynnikiem powstania i rozwoju miast bez względu na epokę historyczną. 


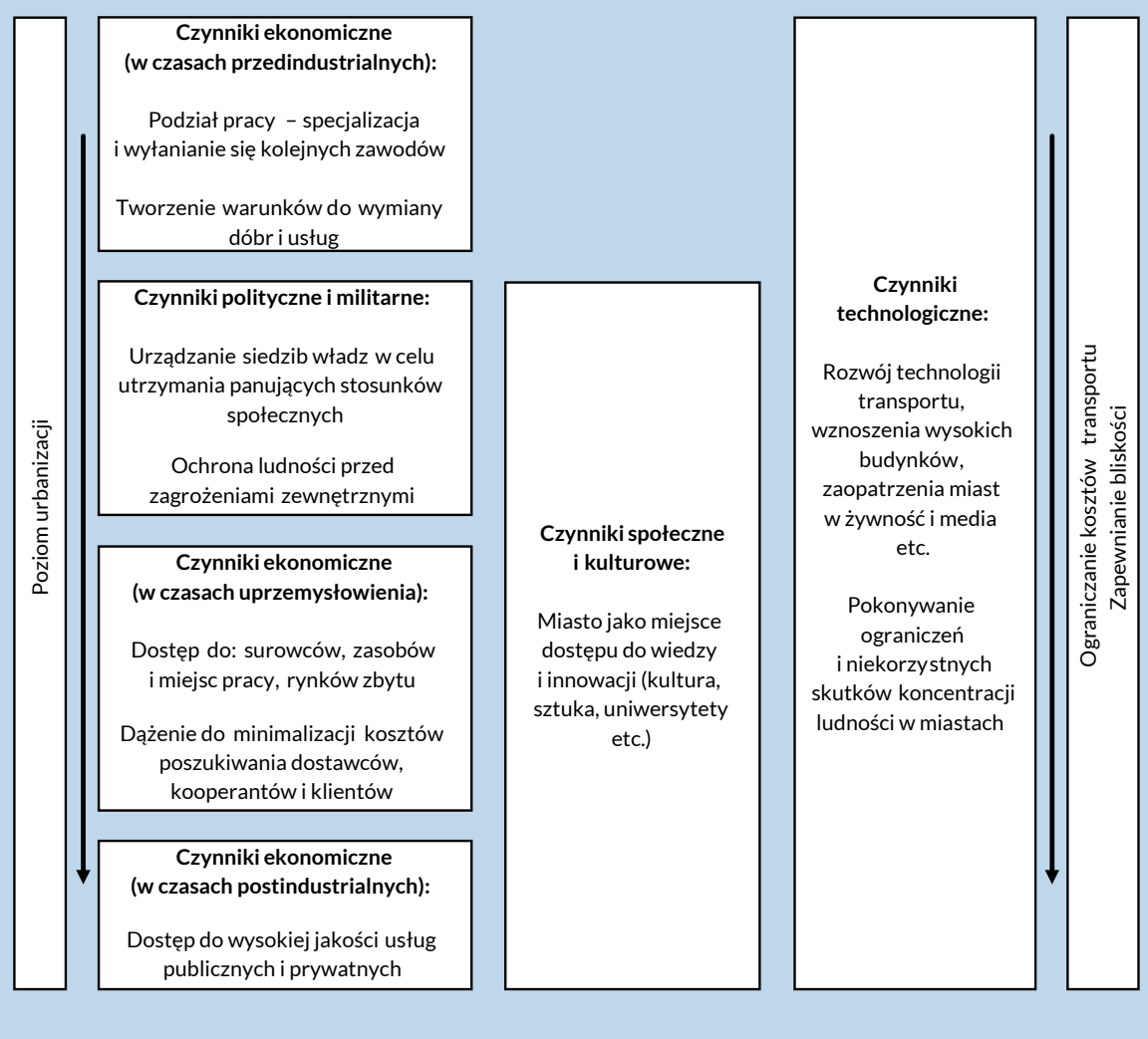

Źródto: opracowanie własne.

Niezależnie od czynników ekonomicznych, politycznych i militarnych niemal od zawsze ważnymi okolicznościami sprzyjającymi rozwojowi miast były też względy społeczne, kulturowe oraz technologiczne. Od czasów ukształtowania się pierwszych hierarchii osadniczych miasta jawiły się jako miejsca dostępu do wiedzy i innowacji oraz rozwoju kultury i sztuki. Ponadto miasta stwarzały okazję do rozwoju myśli technologicznej i wykorzystania jej efektów w celu pokonywania ograniczeń i niekorzyści koncentracji ludności w miastach (rozwój technologii transportu, nowe techniki budownictwa, zaopatrzenie miast w media itp.). Wszystkie te czynniki wzajemnie się wzmacniały, prowadząc do nieustannego wzrostu odsetka ludności zamieszkującej miasta w stosunku do ogólnej liczby ludności świata.

Obecnie najważniejszym czynnikiem ekonomicznym sprzyjającym rozwojowi miast są usługi (szczególnie wyższego rzędu). Interesujące jest przy tym, że pomimo schyłku epoki industrialnej i rozwoju nowoczesnych technologii w zakresie komunikowania się, które hipotetycznie ograniczają presję na koncentrację w ośrodkach miejskich, rozwój gospodarki opartej na usługach i rozwój tzw. gospodarki opartej na wiedzy powodują, że proces urbanizacji nadal postępuje. Kiedy bowiem procesy globalizacji i postęp technologiczny doprowadziły do spadku znaczenia miast jako miejsc produkcji dóbr materialnych, pojawiła się silna potrzeba „produkcji” nowych 
pomysłów (innowacji) [Glaeser, 2012, s. 5]. Rozwojowi tych ostatnich sprzyja przede wszystkim bliskość w wymiarze fizycznym, którą w znacznym stopniu zapewniają miasta. Obecnie ważną korzyścią wynikającą z bliskości jest bowiem to, że pociąga ona za sobą ekonomiczne i kulturowe współzależności, prowadzące do budowania relacji zarówno rynkowych, jak i pozarynkowych, opartych na zaufaniu [Sokołowicz, 2013, s. 59-60]. Bezpośrednie kontakty, będące konsekwencją bliskości, w stosunku do kontaktów na odległość (coraz powszechniejszych ze względu na szybki rozwój technologii komunikacyjnych) stają się nie tyle substytutami, ile czynnikami komplementarnymi [McCann, Shefer, 2004]. W konsekwencji współczesna gospodarka opiera się jednocześnie na umiędzynarodowieniu oraz na czerpaniu z zasobów lokalnych.

Ewolucja czynników rozwoju zapisana w krajobrazie miasta

W krajobrazie wielu miast Europy i Ameryki Północnej odnaleźć można ceglane mury fabryk. Pozostają one symbolem gwałtownej industrializacji, choć dziś nie prowadzi się już w nich działalności produkcyjnej. W XIX wieku przemysł był główną siłą napędową gospodarki. Jednak po okresie intensywnego rozwoju niegdysiejsze stolice przemysłowe doświadczyły głębokich przekształceń gospodarczych. Liczba miejsc pracy w sektorze przemysłowym zaczęła maleć za sprawą dążenia przedsiębiorstw do minimalizacji kosztów, co osiągano poprzez mechanizację produkcji oraz przenoszenie jej do krajów o niższych kosztach pracy. Mury fabryczne, w których jeszcze niedawno słyszano stuk maszyn, zaczęły pustoszeć, a sektorami, które zaczęły przejmować wiodącą rolę w napędzaniu gospodarek miejskich, stały się specjalistyczne usługi oraz działalność innowacyjna [Moretti, 2013, s. 30-32]. Ilustracją tych zmian mogą być m.in. zabudowania fabryki Ramischa przy ulicy Piotrkowskiej w Łodzi, gdzie w XIX wieku produkowano wyroby bawełniane. Po zaprzestaniu produkcji budynki na kilka lat opustoszały. Wkrótce zaczęły one jednak gościć małe przedsiębiorstwa usługowe i produkcyjne zakładane przez młodych mieszkańców miasta. Jednym z nich jest sklep „Pan tu nie stał”, oferujący odzież produkowaną w Łodzi pod tą samą marką. Fabryka, w której niegdyś robotnicy wytwarzali produkty bawełniane na masową skalę, stała się miejscem, w którym łodzianie (w znacznej mierze pracujący poza przemysłem) nabywają dobra wytwarzane lokalnie na ograniczoną skalę (także z branży włókienniczej) oraz spędzają wolny czas.

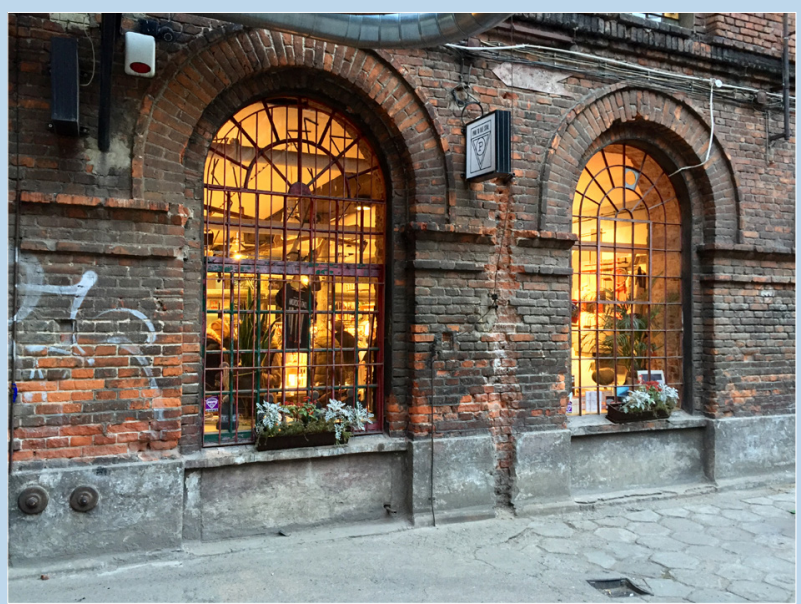

Fotografia 2.1.

Sklep „Pan tu nie stał” w dawnej fabryce Ramischa w Łodzi Fot. Jakub Zasina 
Dopóki ludzie znajdują powody, dla których uznają, że warto przebywać blisko siebie, dopóty będzie istniało zapotrzebowanie na miasta. Choć jeszcze kilkanaście lat temu mogło się wydawać, że wraz z rozwojem sieci telefonicznej i internetowej ludzie porzucą miasta, zaczną zamieszkiwać z dala od siebie i pracować zdalnie za pomocą nowych technologii, zapotrzebowanie na bliskość przestrzenną, którą oferują miasta, jeszcze wzrosło. Okazuje się, że wraz z postępem technologicznym rośnie wśród ludzi konieczność przekazywania wiedzy i umiejętności, a te najefektywniej przenosi się w kontaktach bezpośrednich. Miasta, które koncentrują w sobie przedstawicieli różnych profesji na relatywnie małym obszarze, ułatwiają nawiązywanie bezpośrednich relacji. Aczkolwiek przez wiele lat trudno było udowodnić, że bliskość przestrzenna odgrywa istotną rolę w tworzeniu nowej wiedzy oraz innowacji. Przełomem okazało się badanie przeprowadzone przez A. Jaffego, M. Trajtenberga oraz R. Henderson. Przeanalizowali oni wnioski patentowe składane przez wynalazców. Autor patentu ma obowiązek wskazać autorów wcześniejszych wynalazków, których elementy są wykorzystywane w zgłaszanej propozycji. Wspomniani badacze zauważyli, że wynalazcy we wnioskach patentowych częściej cytują osoby, które pracują nieopodal. Innymi słowy, zasugerowali, że wynalazcy częściej posługują się wiedzą koleżanek i kolegów z bliskiego otoczenia niż osób z odległych lokalizacji. Był to dla nich dowód na to, że bliskość przestrzenna ułatwia przekazywanie wiedzy i umiejętności [Jaffe et al., 1993; Moretti, 2013, s. 142].

Tabela 2.2. Uniwersalne i specyficzne czynniki powstawania i rozwoju miast

\begin{tabular}{|c|c|}
\hline $\begin{array}{c}\text { CZYNNIKI UNIWERSALNE } \\
\text { Dlaczego powstają i rozwijają się miasta? }\end{array}$ & $\begin{array}{c}\text { CZYNNIKI SPECYFICZNE } \\
\text { Dlaczego miasta różnią się między sobą? }\end{array}$ \\
\hline $\begin{array}{l}\text { (w tymewnienie miejsc wymiany dóbr i usług } \\
\text { (wizacja kosztów transakcyjnych). } \\
\text { Lokalizacja siedzib władz. } \\
\text { Zapewnienie bliskości do: } \\
\text { - zasobów materialnych; } \\
\text { - rynków pracy; } \\
\text { - siły roboczej; } \\
\text { - rynków zbytu; } \\
\text { - miejsc sprzedaży dóbr i usług; } \\
\text { - kooperantów; } \\
\text { - kultury i sztuki; } \\
\text { - wiedzy i innowacji. } \\
\text { Dążenie do osiągnięcia skali produkcji i kon- } \\
\text { sumpcji. }\end{array}$ & $\begin{array}{l}\text { Zróżnicowanie warunków naturalnych lokali- } \\
\text { zacji miast. } \\
\text { Dążenie do specjalizacji gospodarczej środków } \\
\text { miejskich (zróżnicowanie tzw. bazy ekono- } \\
\text { micznej miast). } \\
\text { Różnice w sile korzyści skali w różnych typach } \\
\text { działalności gospodarczych. } \\
\text { Różnice w poziomie efektywności zarządzania } \\
\text { miastami. } \\
\text { Zależność rozwoju miastod decyzji politycz- } \\
\text { nych. } \\
\text { Zależność od tendencji ogólnoświatowych } \\
\text { (np. zjawiska metropolizacji gospodarki). }\end{array}$ \\
\hline
\end{tabular}


Podsumowując przegląd kluczowych czynników decydujących o powstawaniu i rozwoju miast, można stwierdzić, że bez względu na odmienny kontekst procesów urbanizacji w różnych epokach historycznych o dynamice i nieuchronności procesów urbanizacji od zawsze decydowały ludzkie potrzeby. Uniwersalność części z tych potrzeb pozwala wyróżnić czynniki wyjaśniające proces urbanizacji (czynniki te były ważne w czasach narodzin pierwszych miast, w okresie rewolucji przemysłowej i pozostają ważne do dziś). Natomiast takie zjawiska, jak zróżnicowanie warunków naturalnych, dążenie poszczególnych ośrodków miejskich do specjalizacji gospodarczej, uwarunkowania polityczne czy wreszcie różnice w umiejętności zarządzania miastami, jawią się jako różnicujące czynniki specyficzne, które w znacznej mierze decydują o sile poszczególnych miast w hierarchii osadniczej, jak i o specjalizacji funkcjonalnej miast (tab. 2.2).

\section{Bibliografia}

Claval P. (1981), La logique des villes, Librairies Techniques, Paris.

Bairoch P. (1985), De Jéricho à Mexico. Villes et économie dans l'histoire, Gallimard, Paris.

Benevolo L. (1995), Miasto w dziejach Europy, Wydawnictwo Krąg \& Oficyna Wydawnicza Volumen, Warszawa.

Bloc-Duraffour P. (1998), Les villes dans le monde, Synthèse, Paris.

Duché G. (2010), Metropolizacja, niezrównoważony wzrost a model globalnej akumulacji. Korzyści i koszty, „Folia Oeconomica”, nr 245.

Glaeser E.L. (2012), Triumph of the city, Penguin Books, London.

Jaffe A.B., Trajtenberg M., Henderson R. (1993), Geographic Localization of Knowledge Spillovers as Evidenced by Patent Citations, „The Quarterly Journal of Economics”, $\mathrm{nr}$ 108(3).

Jewtuchowicz A. (1987), Efekty zewnętrzne w procesach urbanizacji i uprzemysłowienia, Acta Universitatis Lodziensis, Łódź.

Majer A. (2010), Socjologia i przestrzeń miejska, Wydawnictwo Naukowe PWN, Warszawa.

McCann Ph., Shefer D. (2004), Location, Agglomeration, Infrastructure,

„Papers in Regional Science”, nr 83.

Moretti E. (2013), The New Geography of Jobs, Mariner Books, Boston-New York.

O'Sullivan A. (2007), Urban Economics, McGraw Hill-Irwin, New York.

Polèse M. (1994), Economie urbaine et régionale; Logique spatiale des mutations économiques, Economica, Paris.

Population Division of the Department of Economic and Social Affairs of the United Nations Secretariat (2014), World Population Prospects: The 2014 Revision, http:// esa.un.org/unpd/wup/CD-ROM/WUP2014_XLS_CD_FILES/WUP2014-F02-Proportion_Urban.xls. Data dostępu: 12.10 .2015 r.

Sokołowicz M.E. (2013), Zagadnienie bliskości w badaniach nad rozwojem terytorialnym. Podejście instytucjonalne, [w:] A. Nowakowska (red.), Zrozumieć terytorium. Idea i praktyka, Wydawnictwo Uniwersytetu Łódzkiego, Łódź. 


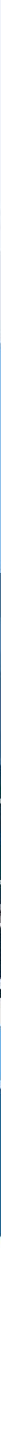

